\title{
オーステナイト結晶粒度の現出に関する研究* \\ 浅田千秋**・閏胳亮*** \\ A STUDY ON THE METHOD FOR REVEALING THE AUSTENITE GRAIN SIZE IN STEEL
}

Synopsis:

\author{
Chiaki Asada, Dr. Eng. and Ryo Kadowaki
}

In the present investigation, the authors developed the new method for revealing the austenite grain boundaries in the steels. The new method contained the special polishing and the proper etching of the specimens which were hardened and tempered to the brittle sorbitic structure.

The results obtained in this investigation are summarized as follows:

(1) When the specimens are rapidly cooled and tempered in $550^{\circ} \mathrm{C}$, the austenite grain! boundaries can be revealed with the etchant $\left(\mathrm{Fe} \mathrm{Cl}_{3}-\mathrm{HCl}\right.$ alcohol solution).

(2) The grain boundaries are revealed by the dark field illumination. in details rather than by bright field illumination.

(3) The actual austenite grain sizes are more easily estimated by the new method, and the results coincide with the grain sizes obtained by the carburizing method under the same austenitizing conditions.

\section{I. 緒 言}

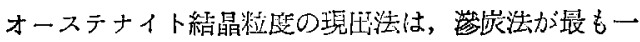

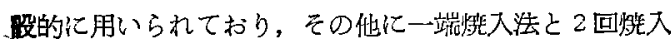
港がしばしば用いられている。これ等の方法はわが国で も学㻺 19 委員经で判定されているが，何れも $925^{\circ} \mathrm{C}$ に加熱した場合におけるオーステナイト粒度の現汇法で あつて，肌焼鉬などはこの方法でよい訳であるが，普通 の精造用鋼などにてれ等の力法を適用すると実際の蓺㚭 理温度における粒度と罢なつた粒度を示す惧れがある。 徉つて $925^{\circ} \mathrm{C}$ におけるオーステナイト粒度の現罒法と は別に，実際の熱処理温度におけるオーステナイト粒度 の現缺法を判定しておく必要がある. 熱処理粒度测定法 としては，笑際の熱処理温度における徐泠法，一端焼入 洪，2回焼入法，酸化法わよび焼入焼庝法等があるが， いずれも一長一短があり，いずれの方法が最良というわ けにはいかない，焼入焼戻法については，国に米国の Vilella と Bain1) 等の研究がありすすでに SAEわよび ASTM の瞡格にも制定されている．との方法は鋼材を 所定の温度で焼入した後, $200^{\circ} \mathrm{C} \sim 250^{\circ} \mathrm{C}$ の低温でマル テンサイトの焼戻を行い，特殊な窝飭液で慨を行つて オーステナ.イト結晶粒の方优の差を観祭して测定する方 洗である。

著者等かとこに述べようさす万法は，Vilella and Bain，法とおなしく焼入烧杘を行つてオーステナイト粒 度を現出する方法であるが，Vilella and Bain 法が低
温然压による晲代法であるのに対し，著者等の方法は高 温燃度 $\left(550^{\circ} \mathrm{C}\right)$ を行つて現画する方法であり，窗蝕法 も前者と䍗なつた方法を用いる。これは多くの特殊鎆が $550^{\circ} \mathrm{C}$ 附近において燃㞔脆性を示しており，てれ伴つ

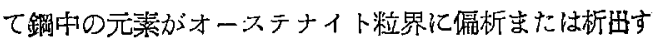
る現象に前目したもので, 以下この方法について述べよ うとするものである.

\section{II. 試料及び実験方法}

笑験に用いた武料は Table 1 亿示した肌烧銅第8種 (SH 95)， Cr 鋼第 4 種 (SCr 90)， Ni-Cr-Mo 銅 (SAE 8647) および Si-Mn-Cr 鋼の 4 鍴種を選んだ 後つぎの如き熱処理を行つた.すなわち,

$$
\text { SH } 95870^{\circ} \mathrm{C} \sim 1 \mathrm{~h} \quad \text { O.Q. }
$$$$
\mathrm{SCr} 90850^{\circ} \mathrm{C} \times 1 \mathrm{~h} \quad \text { O.Q. }
$$

SAE $8647870^{\circ} \mathrm{C} \times 1 \mathrm{~h} \quad$ O.Q.

$\mathrm{Si}-\mathrm{Mn}-\mathrm{Cr}$ 鋼 $870^{\circ} \mathrm{C} \times 1 \mathrm{~h}$ O.Q.

上上の如き炕入を行つた後, $100^{\circ} \mathrm{C}, 200^{\circ} \mathrm{C}, 300^{\circ} \mathrm{C}$, $400^{\circ} \mathrm{C}, 500^{\circ} \mathrm{C}, 550^{\circ} \mathrm{C}, 600^{\circ} \mathrm{C}$ および $650^{\circ} \mathrm{C}$ の各温度 に2 h 保持して㜔戻を行い，各温度における衝慗值と才 リネル硬度を求めた。なお， $250^{\circ} \mathrm{C}$ と $550^{\circ} \mathrm{C}$ 亿おける

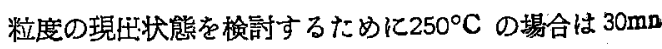

* 昭和 30 年 10 月本会諩演大会にて発表

**大同留銓株式会社, 工学博士

*****同製銧株式会社 
Table 1. Chemical composition of specimens.

\begin{tabular}{|c|c|c|c|c|c|c|c|c|c|c|}
\hline \multirow{2}{*}{ Steel } & \multicolumn{9}{|c|}{ Chemical composition } & \multirow{2}{*}{ Remarks } \\
\hline & C & $\mathrm{Si}$ & Mn & $\mathrm{P}$ & S & $\mathrm{Cu}$ & $\mathrm{Ni}$ & $\mathrm{Cr}$ & Mo & \\
\hline SH 95 & 0.21 & $0 \cdot 34$ & $0 \cdot 81$ & 0.020 & 0.004 & 0.20 & 0.11 & $1 \cdot 08$ & $0 \cdot 27$ & $\begin{array}{l}22 \Phi \text { Rod } \\
870^{\circ} \mathrm{C} \times 1 \mathrm{~h}\end{array}$ Annealed \\
\hline $\operatorname{SCr} 90$ & 0.42 & $0 \cdot 28$ & 0.68 & 0.024 & 0.023 & $0 \cdot 35$ & $0 \cdot 12$ & $1 \cdot 12$ & & $\begin{array}{l}22 \oint^{\circ} \mathrm{Rod} \\
850^{\circ} \mathrm{C} \times 1 \mathrm{~h}\end{array}$ \\
\hline SAE 8647 & 0.48 & 0.33 & $0 \cdot 89$ & 0.015 & 0.018 & 0.22 & 0.51 & $0 \cdot 49$ & $0 \cdot 20$ & 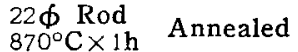 \\
\hline $\begin{array}{c}\mathrm{Si}-\mathrm{Mn}-\mathrm{Cr} \\
\text { steel }\end{array}$ & 0.38 & 0.90 & 0.99 & 0.015 & 0.016 & $0 \cdot 24$ & 0.13 & $0 \cdot 13$ & & $\begin{array}{l}16 \times 40 \text { Flat bar } \\
870^{\circ} \mathrm{C} \times 1 \mathrm{~h} \text { Annealed }\end{array}$ \\
\hline
\end{tabular}

と $1 \mathrm{~h}$ 保持して急冷し， $550^{\circ} \dot{\mathrm{C}}$ の場合は保持時間の影

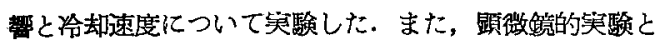

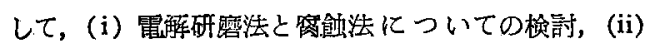

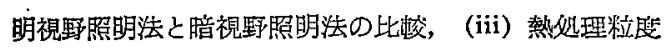
と炭粒度の比晈わよび (iv) 熱㐫理粒度と破面粒度の 比榕, 等沉ついて行つた.

\section{III. 実 驗 結 果}

\section{(1.) 機械試験}

Table 1 亿示した 4 種の語料について焼入を行つた 後, $100^{\circ} \mathrm{C} \sim 650^{\circ} \mathrm{C}$ の各温度で焼戻を行つて，そのシャ ルピー值とブリネル硬度を求めた. 結果は Fig. 1 亿示

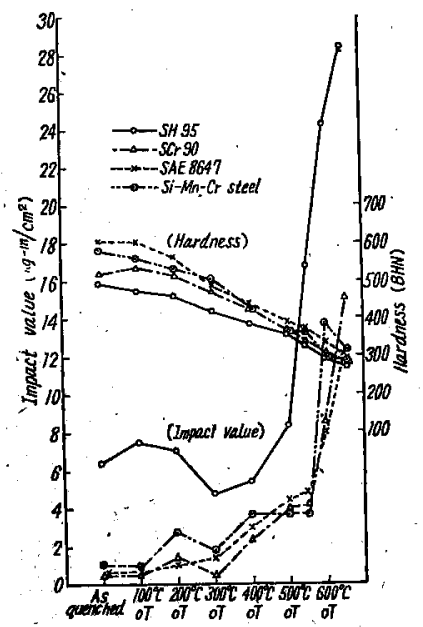

Fig. 1. Mechanical properties at various tempering temperatures.

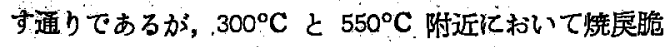
性によるシャルピー值の低下している状態が認められ ろ. とくに $550^{\circ} \mathrm{C}$ 附近にわける脆性点では, Si-Mn-Cr

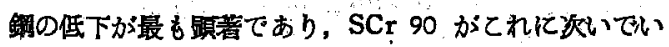
љ.

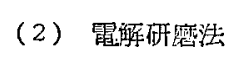

征整試踰後の試歌片を顕微鏡試料として,グラインダ 一よりエメリーペーパー（０00）まで庄延方向について

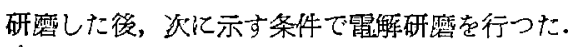

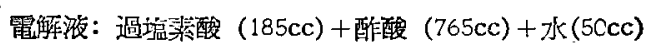

電圧： $28 \mathrm{~V}$

雷流密度: $1 \cdot 2 \mathrm{~A} / \mathrm{cm}^{2}$

溜温: $20^{\circ} \mathrm{C} \sim 25^{\circ} \mathrm{C}$

極間距斉: $15 \mathrm{~mm}$

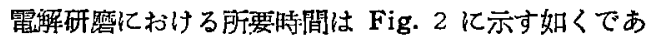
り，約 $15 \mathrm{sec} よ り 20 \mathrm{sec}$ の間において $100 \%$ の研花

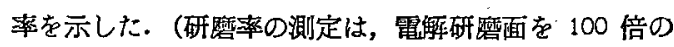
顕钽鏡で観察し，完全研磨部と不完全研磨部の面積比を 湘定したものである.)

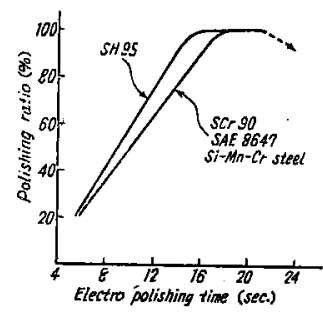

Fig, 2. Relation between electro-polishing time and electro polishing ratio.

わなお，機峨的研磨と電解研磨による試料表面について ライツ微小硬度計（荷董 $50 \mathrm{~g}$ ）で表面硬度を测定する

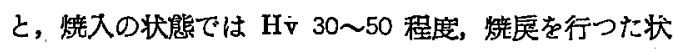
態では $\mathrm{Hv} 10$ 程度の硬度差が生じており，何れの場合

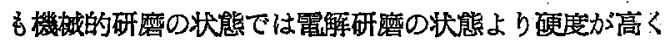
現われている：てれは武料表面に生じた加工硬化層 (Beilby 層) の存在を意味していることは眀らかであ り，オーステナイト粒度を現田する際も，電解研磨によ

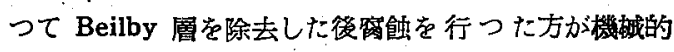
研磨の埸合よりも好結果が得られた. Fig. 3 は SH 95 


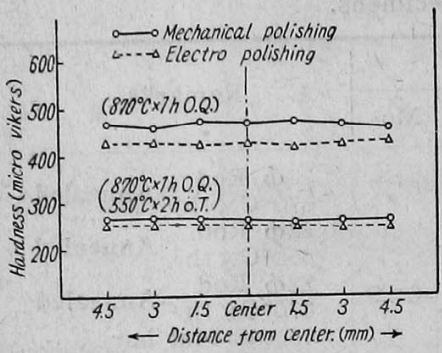

Fig. 3. Comparison of the surface hardness between mechanical polishing and electropolishing.

(Leitz micro-Vickers hardness tester. $\mathrm{P}=50 \mathrm{~g}$ )

そついて微小硬庭を測定した結果である.

(3) 腐蝓法

腐蝕剤は次に示す 5 種について笑験を行つた.すなわ ち,

(A) ピクリン酸アルコール溶液

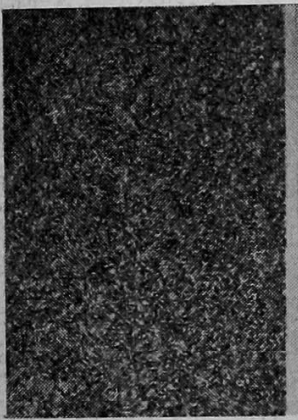

$5 \%$ Picral

(SH95)

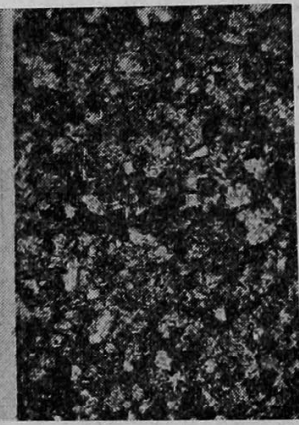

$\mathrm{FeCl}_{3}-\mathrm{HCl}$ alcohl solution

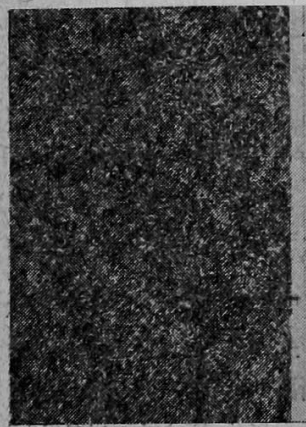

$5 \%$ Picral

(SAE8647)

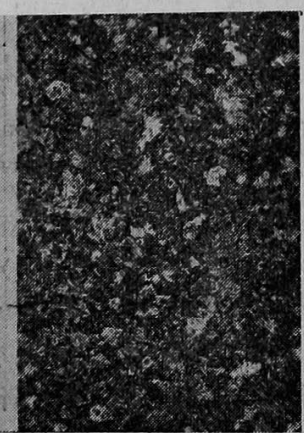

$\mathrm{FeCl}_{3}-\mathrm{HCl}$ álcohl

solution

(B) $2 \%$ 硝酸アルコール溶液

(C) ピクリン酸飽和水溶液

(D) Vilella and Bain 試楽

（1）ピクリン酸 $1 \mathrm{~g}$, 濃站酸 $5 \mathrm{cc}$ ，エチルアルコ ール $65 \mathrm{cc}$

(2) 瑥化第 2 鉄 $5 \%$ 水溶液

(E) 塭化第 2 鉄坥酸アルコール浴液

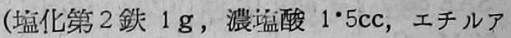
ルコール 100cc)

以上に示した胬蝕戍の中で，(A) 刘と（B）刘は特 殊鋼の顕微鏡組織検售用として最も広く用いられており

(C) 剂は焼戻脆性組織の秝梽用として，B，C.

Woodfine 等2) が用いた腐领绪でである.（D) 剂は前 述した如くVilella と Bain が捹大後低温焼民を行う

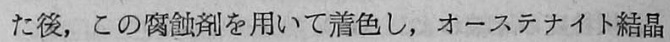
粒の方位の差を観察したものである.また，（E）用は 者者等がオーステナイ粒度現出の目的で調整したもので ある.これは, オーステナイト粒界の窗蝕には塩酸が最

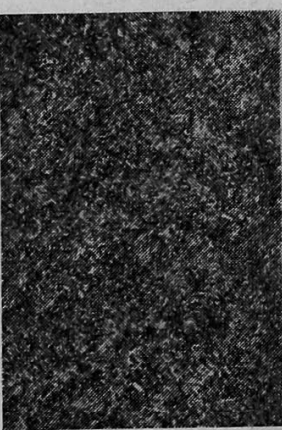

$5 \%$ Picral (SCr90)

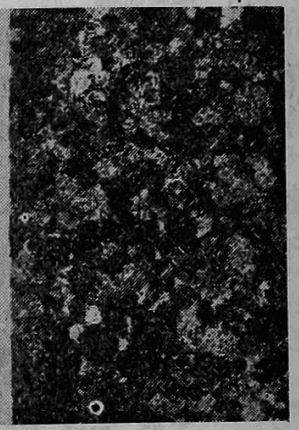

$\mathrm{FeCl}_{3}-\mathrm{HCl}$ alcohl solution

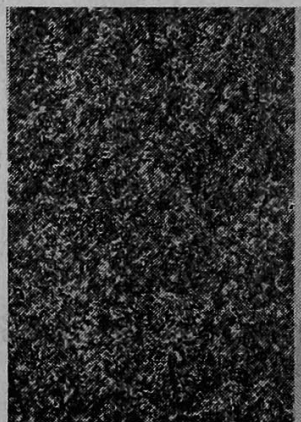

$5 \%$ Picral

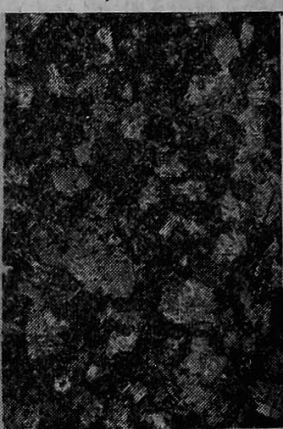

$\mathrm{FeCl}_{3}-\mathrm{HCl}$ alcohl ( $\mathrm{Si}-\mathrm{Mn}-\mathrm{Cr}$ steel) solution

Photo. 1. The various microstructures etched with $5 \%$ picral and $(1 \mathrm{~g} \mathrm{FeCl}+1 \cdot 5 \mathrm{cc}$ $\mathrm{HCl}+100 \mathrm{cc} \mathrm{C}_{2} \mathrm{H}_{5} \mathrm{OH}$ ) solution, showing the apparent differences in these etchants.

Specimens slowly cooled from $550^{\circ} \mathrm{C} .(\times 100)$ 
も効果的であるととを氝験の結果知ることが非来，微量 の掹化第 2 鉄とともにエチルアルコールに浴解して, 粒 界の窝飾を徐々に行うべく調整したものである（窝蝓

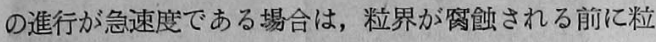
内が窝領されやすく，粒内と粒界の判別が困難になる.) 腐玲の結果を示すと，(A) 剂と（B）刘は粒㡶の現出 か困難であり，(C) 剂はやや明䐲に現出されるが，粒 度の測定は不可能である。（D）剂と（E）剂は前三者 に比酸して粒度の現任が容易であり，又粒度测定も可能 であるが，両窝蝕剤について各焼㞎温度（とくに $250^{\circ} \mathrm{C}$ と $550^{\circ} \mathrm{C}$ ) にわける粒度の現壮状態を比此すると次の 通りである.

(i) $250^{\circ} \mathrm{C}$ 烧戻の場合：保持時間は $30 \mathrm{mn}$ そ $1 \mathrm{~h}$ そて油泠を行つた武料の，(D) 剂と（E）剂による窝领 の䋨果は，両者とも粒磨は明瞭に現われ，保持時間によ

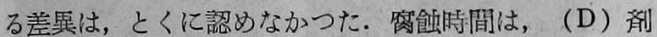
が約 $22 \mathrm{sec}((1)$ 液約 $20 \mathrm{sec}$ ，(2) 液約 2sec） t票し

(E) 刘は約 $1 \mathrm{mn}$ を要した。)

(ii) $550^{\circ} \mathrm{C}$ 㜔戻の場合： $1 \mathrm{~h} ， 2 \mathrm{~h} ， 5 \mathrm{~h}$ および $10 \mathrm{~h}$ 保 持した後，急冾 (油椧) と徐冷 (恼冷) を行つて粒度を 比謇したが，急冷の場合より徐冷の場合の方が粒庱の現 出は容易であつた．また粒度の測定も充分可能であり， $250^{\circ} \mathrm{C}$ の場合よりも優れている。保持時間は $2 \mathrm{~h}$ 上上 を必要とする．向， $650^{\circ} \mathrm{C} て ゙$ 急冷して颉性状態てした後 $550^{\circ} \mathrm{C}$ に再加熱して俆冷すると粒度の現虫が一層容易に なる。腐飾特間は（D）刘が約 $13 \mathrm{sec}$ ((1)液約 $10 \mathrm{sec}$ (2) 液約 2,3sec) を要し，(E) 刘は約 40sec を票し た. 粒度の現专結果は（E）剂の方がよい。

Photo 1 は, $550^{\circ} \mathrm{C}$ で徐冷した場合について.(A)

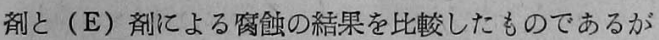

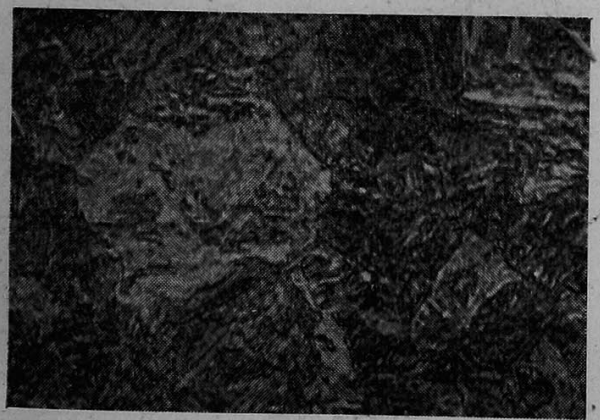

Bright field
(A) 刘ではほとんで粒度が現出されていないのに反し （E都）の場合は明膫に現庍されていることがわかる。

（4）暗視野照明法による粒度の測定 ${ }^{3) 4}$

$550^{\circ} \mathrm{C}$ で徐冷した場合におけるオーステナイト粒度は Photo 1 亿示した如く，普通の明視野照明法でも明瞭 に測定されるが，てれを暗視野照明法で襍察すると，明 視野照明法とは区対の現象が現われて興味深い，すなわ ち，明視野照明法は垂面照明であるために粒界は黒く現 われるが，暗視野照明による場合は傾斜照明であるため 鋼種によつては粒界に析成物が白く連鎖状に現われてい るのを認めるととが出来る．なお，粒内と粒界の対照が 明膫であるために，粒度の測定は明視野照明の場合より 容易である. (Photo. 2 参照)

\section{（5）熱处理粒度と渗宸粒屋の比较}

以上述べた方洗によりオーステナイト粒度を現话した 後，ての方法の实用性を㛟討すべく，從来最も工業的に 用いられている渗炭法と比輍検討した，突鈳に当つては 渗㟶粒度を測定する武料は木炭 $(60)+$ 炭酸バリウム $(40)$ の苶炭函に封入し，また熱拠理粒度を測定する武料は渗 㞸函の隧に位置させた後， $925^{\circ} \mathrm{C}$ 亿 $6 \mathrm{~h}$ 保持した．冾却 の場合は，宸武料は炬内に放置したまま $200^{\circ} \mathrm{C} / \mathrm{h} の$

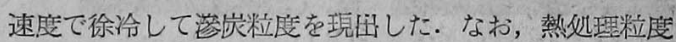
試料は直ちに师中より取り医して油中に焼入れした後，

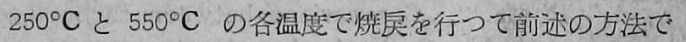

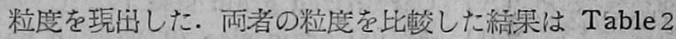
に示したが，测定数值はほとんど一致しており，本法に よる熱処理粒度は审用上の精廃を有していることを認め †. (Photo 3 参照)

なお，熱处理粒度を高倍率で見ると，オーステナイト 粒内に幾多の Subgrain が認められ，てれによつて粒

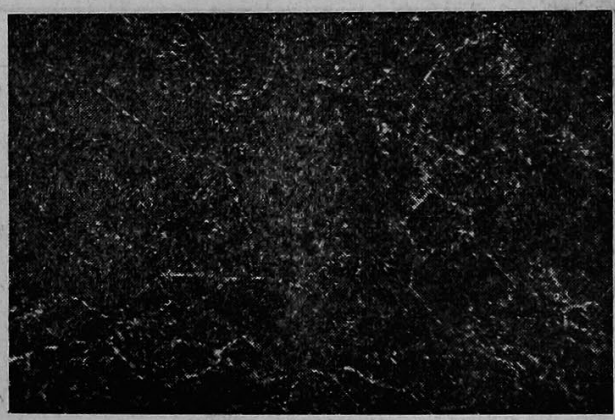

Dark field

Photo. 2. Microstructures of a temper brittle specimen shown by bright field and dark field illumination.

$\left(\mathrm{Si}-\mathrm{Mn}-\mathrm{Cr}\right.$ steel, $870^{\circ} \mathrm{C}$ O.Q. $550^{\circ} \mathrm{C}$ F.C. $\left.\times 500\right)$ 


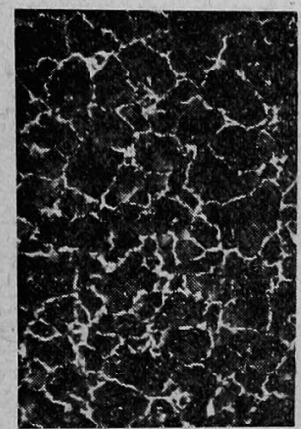

(A)

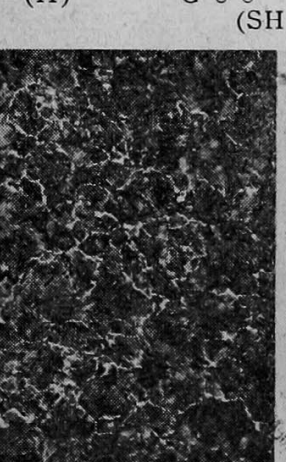

(A)

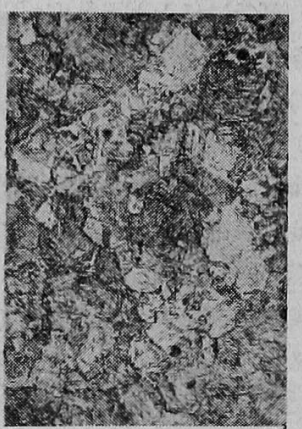

(B) 95)

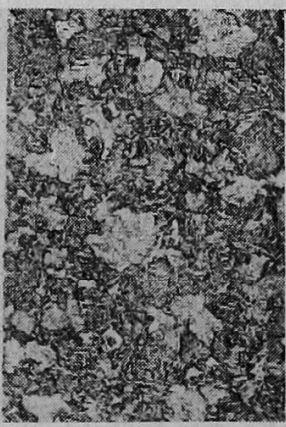

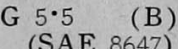

G $5 \cdot 3$

Photo. 3. Comparison between carburized grain size and actual grain size. $(\times 100)$

(A) Carburized grain size $\left(925^{\circ} \mathrm{C} \times 6 \mathrm{~h}\right.$ carburized)

(B) Actual grain size $\left(925^{\circ} \mathrm{C} \times 6 \mathrm{~h}\right.$ hardened and $550^{\circ} \mathrm{C} \times 2 \mathrm{~h}$ slowly cooled)

度の测定を誤り易いか;，Subgrain の粒界はオーステナ イトの粒界に比して謪领が浅いため，位倍率による粒度 の測定には支障にはならない。

Table 2. Relation between carburized grain size and actual grain size.

\begin{tabular}{|c|c|c|c|c|}
\hline \multirow[b]{2}{*}{ Steel } & \multicolumn{2}{|c|}{$\begin{array}{c}\text { Carburized } \\
\text { grain size }\end{array}$} & \multicolumn{2}{|c|}{ Actual grain size } \\
\hline & & $\begin{array}{l}{ }^{\circ} \mathrm{C} \times 6 \mathrm{~h} \\
\text { burized }\end{array}$ & $\begin{array}{r}925^{\circ} \mathrm{C} \times 6 \mathrm{~h} \\
\text { O.Q. } \\
250^{\circ} \mathrm{C} \times 1 \mathrm{~h} \\
\text { O.T. }\end{array}$ & $\begin{array}{r}925^{\circ} \mathrm{C} \times 6 \mathrm{~h} \\
\mathrm{O} . \mathrm{Q} . \\
550^{\circ} \mathrm{C} \times 2 \mathrm{~h} \\
\mathrm{~F} . \mathrm{C} .\end{array}$ \\
\hline $\mathrm{SH} 95$ & G & $5^{\bullet} 0$ & $5 \cdot 2$ & $5 \cdot 3$ \\
\hline Scr 90 & & $5 \cdot 1$ & $5 \cdot 5$ & $5 \cdot 3$ \\
\hline SAE 8647 & & $5 \cdot 5$ & $5 \cdot 2$ & $5 \cdot 3$ \\
\hline $\begin{array}{c}\mathrm{Si}-\mathrm{Mn}-\mathrm{Cr} \\
\text { steel }\end{array}$ & & $5 \cdot 1$ & $5 \cdot 3$ & $5 \cdot 0$ \\
\hline
\end{tabular}

（6）熱処理粒度と破面粒度の比較

焼入状態および焼入後 $100^{\circ} \mathrm{C} よ り 650^{\circ} \mathrm{C}$ までの各温 度で焼杘を行つた武料の破面について，Jernkontoret 法により破面粒度を測定し，熱処理粒度と比較した。結
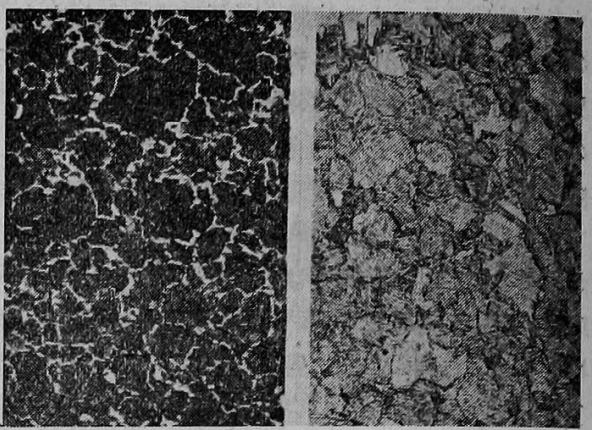

(A)

G $5 \cdot 1$ ( $\mathrm{SCr} 90)$

$\mathrm{G} 5 \cdot 3$

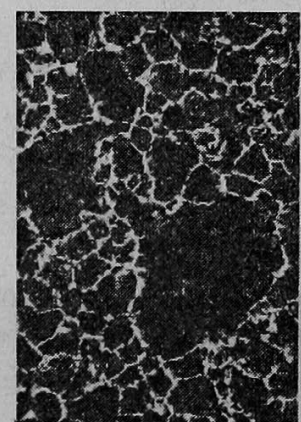

(A)

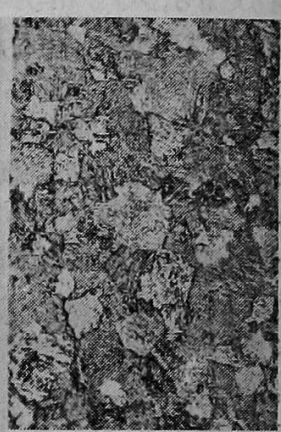

(B)

$5 \cdot 0$

果は Table 3 に示す如く両者の測定值ははぼ一致して おり，両者間には直線的な関係のあることぶ認められ た. (Fig. 4 参照)

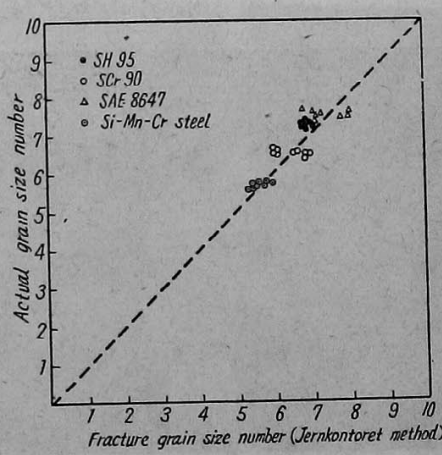

Fig. 4. Relation between fracture grain size and actual grain size. 
Table 3. Relation between fracture grain size and actual grain size.

\begin{tabular}{|c|c|c|c|c|c|c|c|c|}
\hline \multirow{2}{*}{ treatment } & \multicolumn{2}{|c|}{ SH 95} & \multicolumn{2}{|c|}{$\operatorname{SCr} 90$} & \multicolumn{2}{|c|}{ SAE 8647} & \multicolumn{2}{|c|}{$\mathrm{Si}-\mathrm{Mn}-\mathrm{Cr}$ steel } \\
\hline & \begin{tabular}{|l} 
Fracture \\
grain size
\end{tabular} & $\begin{array}{l}\text { Actual } \\
\text { grain size }\end{array}$ & $\begin{array}{l}\text { Fracture } \\
\text { grain size }\end{array}$ & $\begin{array}{l}\text { Actual } \\
\text { grain size }\end{array}$ & $\begin{array}{l}\text { Fracture } \\
\text { grain size }\end{array}$ & $\begin{array}{l}\text { Actual } \\
\text { grain size }\end{array}$ & $\begin{array}{l}\text { Fracture } \\
\text { grain size }\end{array}$ & $\begin{array}{l}\text { Actual } \\
\text { grain size }\end{array}$ \\
\hline $\begin{array}{c}\text { As quenched } \\
100^{\circ} \mathrm{C} \text { O.T. } \\
200^{\circ} \mathrm{C} \text { O.T. } \\
300^{\circ} \mathrm{C} \text { O.T. } \\
400^{\circ} \mathrm{C} \text { O.T. } \\
500^{\circ} \mathrm{C} \text { O.T. } \\
550^{\circ} \mathrm{C} \text { O.T. } \\
600^{\circ} \mathrm{C} \text { O.T. } \\
650^{\circ} \mathrm{C} \text { O.T. }\end{array}$ & \begin{tabular}{|c|}
7 \\
7 \\
7 \\
$6 \cdot 7$ \\
$6 \cdot 7$ \\
$6 \cdot 7$ \\
$6 \cdot 7$ \\
$6 \cdot 7$ \\
$6 \cdot 7$
\end{tabular} & $\begin{array}{l}7 \cdot 1 \\
7 \cdot 2 \\
7 \cdot 2 \\
7 \cdot 2 \\
7.2 \\
7 \cdot 2 \\
7 \cdot 2 \\
7 \cdot 2 \\
7 \cdot 1\end{array}$ & \begin{tabular}{|l|}
7 \\
7 \\
7 \\
$6 \cdot 7$ \\
$6 \cdot 7$ \\
6 \\
6 \\
6 \\
6
\end{tabular} & $\begin{array}{l}6 \cdot 6 \text { (?) } \\
6 \cdot 7 \text { (?) } \\
6 \cdot 7 \\
6 \cdot 7 \\
6 \cdot 7 \\
6 \cdot 8 \\
6 \cdot 5 \\
6 \cdot 7 \\
6 \cdot 7\end{array}$ & $\begin{array}{l}8 \\
8 \\
7 \cdot 8 \\
7 \\
7 \\
7 \\
7 \\
7 \\
7\end{array}$ & \begin{tabular}{|l|}
$7 \cdot 4$ \\
$7 \cdot 5(?)$ \\
$7 \cdot 3$ \\
$7 \cdot 4$ \\
$7 \cdot 3$ \\
$7 \cdot 3$ \\
$7 \cdot 3$ \\
$7 \cdot 5$ \\
$7 \cdot 4$ \\
$7 \cdot 4$
\end{tabular} & $\begin{array}{l}6 \\
6 \\
6 \\
5 \cdot 5 \\
5 \cdot 5 \\
5 \cdot 5 \\
5 \cdot 5 \\
5 \cdot 5 \\
5 \cdot 5\end{array}$ & $\begin{array}{l}5 \cdot 8(?) \\
5 \cdot 8(?) \\
5 \cdot 7 \\
5 \cdot 8 \\
5 \cdot 6 \\
5 \cdot 8 \\
5 \cdot 7 \\
5 \cdot 8 \\
5 \cdot 7\end{array}$ \\
\hline
\end{tabular}

\section{IV. 結 言}

$925^{\circ} \mathrm{C}$ 亿わけるいわ的炭粒度とは於に，实際の熱 处理状態における熱処理粒度を知る必票がある．著者等 はこの方法の一つとして，皘造用特殊鋼の㹸庆の際に起

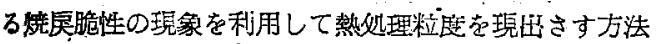
について研究を行つた．なお徉来おなじく烧入烧戻法と して行われている Vilella および Bain の低温燒扈法 $\left(250^{\circ} \mathrm{C}\right)$ も併せて武験した. 実験に使用した鍓種は肌 焼鋼第8 種, クロム錀第 4 㮔, SAE 8647.および Si-

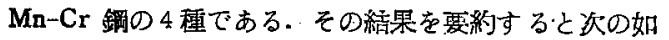
くである.

(i) $250^{\circ} \mathrm{C}$ で㜔戻した場合：保持明間に関係なく， Vilella 試薬, 垭化第 2 鉄盖酸アルコール溶液ともに才 ースナイト粒度の現居は容易である。

(ii) $550^{\circ} \mathrm{C}$ で焷送した場合：焼戻後急冷した埸合よ り徐椧した埸合がく，保持時間は $2 \mathrm{~h}$ 以上を必要とす る.なお,塭化第 2 銖壏酸アルコール浴液の方が Vilella 試薬よりも操作が容易であり，粒度の現圈も眀瞭である。

(iii) $250^{\circ} \mathrm{C}$ と $550^{\circ} \mathrm{C}$ の場合を比輍すると，前者が マルテンサイト結晶粒の窗蝕であるのに反し後者は元素 の粒界偏析を利用した粒界窝蝕であり，粒度見出の容易
な点において後者の方が儒れている。

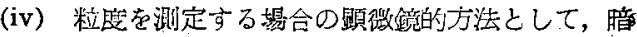
視照明について实駼したが，粒界と粒内の対照が明瞭に 現われ，測定か溶易に出来た。

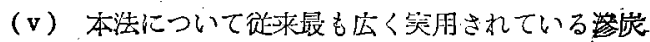
法と比輘したが，雨者の測定值ははとんど一致してお゙ り・本法の突用上の精度はよいととを認めた。なお， Jernkontoret 法による破面粒度と比较をしたが，雨、 者間には园線的な関保のあることを認めた。

以上の阴くであり，ての方法は若千の熟鍊を要するが

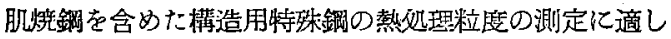
ており，とくに，すでに熱処理珮の試糊について，その 睢のオーステナイト粒度を測定比来る点に特街がある.

(昭和 30 年 12 月知稿)

$$
\text { 文 献 }
$$

1) E. C. Bain and J. R. Vilella: ASM Metals Hand Book (1948) 399

2) B. C. Woodfine: J.I.S.I. Vol. 173, part 3, 240

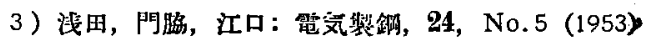
237

4) 阿脇：電気笠鋼，24，No.6 (1953) 285 